\title{
Typical Patterns of Bone Involvement in Whole-Body MRI of Patients with Chronic Recurrent Multifocal Osteomyelitis (CRMO)
}

\section{Typische Muster des Knochenbefalls in der Ganzkörper-MRT von Patienten mit chronisch rekurrierender multifokaler Osteomyelitis (CRMO)}

Authors

Affiliations
T. von Kalle' ${ }^{1}$, N. Heim² , T. Hospach ${ }^{3}$, M. Langendörfer ${ }^{4}$, P. Winkler ${ }^{1}$, T. Stuber ${ }^{1}$

Radiologisches Institut, Olgahospital Klinikum Stuttgart

2 Klinik für Unfallchirurgie und Orthopädie, Katharinenhospital Klinikum Stuttgart

Pädiatrische Rheumatologie, Olgahospital Klinikum Stuttgart

${ }^{4}$ Orthopädische Klinik, Olgahospital Klinikum Stuttgart

Key words
bones
MR imaging
non-bacterial chronic
osteomyelitis
children
adolescents

eingereicht 4.11 .2012

akzeptiert 7.3 .2013

Bibliography

Dol http://dx.doi.org/

10.1055/s-0033-1335283

Published online: 21.5 .2013

Fortschr Röntgenstr 2013; 185:

655-661 @ Georg Thieme

Verlag KG Stuttgart · New York . ISSN 1438-9029

\section{Correspondence}

Dr. Thekla von Kalle

Radiologie, Olgahospital

Klinikum Stuttgart

Bismarckstr. 8

70176 Stuttgart

Germany

Tel.: ++ 49/7 11/278-73301

Fax: ++ 49/7 11/2 78-73409

t.vonkalle@klinikum-

stuttgart.de

\section{Zusammenfassung \\ $\nabla$}

Ziel: Die Diagnose einer CRMO wird häufig erst nach einer längeren Anamnese gestellt. Wir werteten Ganzkörper-MRT (GK-MRT) hinsichtlich typischer Muster des Knochenbefalls aus und beurteilten deren potentiellen Beitrag zu einer schnelleren Diagnosestellung.

Material und Methoden: GK-MRT (1,5 T, coronare STIR-Sequenzen) bei 53 Kindern und Adoleszenten (mittleres Alter 11 Jahre, 4,8 - 15,1) mit histologisch $(n=37)$ oder klinisch $(n=16)$ gesicherter CRMO wurden retrospektiv von 2 erfahrenen pädiatrischen Radiologen beurteilt.

Ergebnisse: GK-MRI zeigte multifokale Läsionen von einer Ausnahme abgesehen bei allen Patienten. Nur 26 hatten multifokale Beschwerden angegeben. Wir entdeckten 1-27 geografische Läsionen pro Patient (Mittelwert 9,7). 510 der 513 Läsionen waren deutlich hyperintens im Vergleich zu normalem Knochenmark. Becken, untere Extremitäten, Schultern und Wirbelsäule waren am häufigsten betroffen. 40 Patienten (75\%) hatten beidseitige symmetrische Knochenbeteiligung. Die meisten aller Läsionen traten in Röhrenknochen auf, in $87 \%$ angrenzend an eine Epiphysenfuge. $32 \%$ der Läsionen hatten eine periostale Begleitreaktion. 33 der 456 betroffenen Knochen (7,2\%) waren deformiert, 6 (18\%) waren vertebra plana.

Schlussfolgerung: Da spezifischere Diagnose-Kriterien fehlen, kann die GK-MRT in Zusammenschau mit klinischen Befunden einen wichtigen Beitrag zu einer zügigen Diagnosestellung der CRMO leisten. Sie entdeckt typische Muster des multifokalen und bilateralen Knochenbefalls häufiger als für regionale MRT-Untersuchungen berichtet. Sie zeigt die charakteristische Nähe der Läsionen zu den Epiphysenfugen, zu den Iliosakralgelenken sowie zur Y-Fuge und erlaubt die Entdeckung asymptomatischer spinaler Komplikationen.

\section{Abstract \\ $\nabla$}

Purpose: The diagnosis of CRMO often involves a long patient history. We evaluated the spectrum of bone involvement in whole-body magnetic resonance imaging (WB-MRI) and assessed its potential contribution to a more rapid diagnosis.

Materials and Methods: WB-MRI (1.5 T, coronal STIR sequences) in 53 children and adolescents (mean age 11 years, $4.8-15.1$ ) with histologically $(n=37)$ or clinically $(n=16)$ confirmed CRMO were retrospectively reviewed by two experienced pediatric radiologists.

Results: WB-MRI revealed multifocal lesions in all but one patients. Only 26 of them had presented with multifocal complaints. We detected 1-27 geographic lesions/patient (mean 9.7). 510 of 513 lesions were significantly hyperintense compared to normal bone marrow. The pelvis, lower extremities, shoulders and spine were most frequently involved. 40 patients (75\%) had bilateral symmetrical involvement of bones. Most of the lesions were located in tubular bones, in $87 \%$ adjacent to one or both sides of a growth plate. $32 \%$ of lesions showed periosteal involvement. Of 456 affected bones, 33 (7.2\%) were deformed, 6 (18\%) were vertebra plana.

Conclusion: In the absence of more specific diagnostic criteria, WB-MRI can, in synopsis with clinical findings, substantially contribute to a rapid diagnosis of CRMO. It discovers the typical pattern of multifocal and bilateral bone involvement more often than has been reported for targeted MRI. It readily reveals the characteristic proximity of lesions to growth plates, the sacroiliac joint and triradiate cartilage and helps to uncover asymptomatic spinal complications. 


\section{Introduction}

$\nabla$

First described by Giedion et al. [1] in 1972, CRMO is an increasingly recognized auto-inflammatory non-bacterial disease with multifocal bone lesions that is frequently complicated by vertebral fractures [2, 3]. The alternative, more general term, chronic non-bacterial osteomyelitis (CNO or NBO), has been proposed [4] to better include the aseptic character of the disease. It mainly affects children and adolescents who usually present with pain and movement restrictions. The annual incidence is currently estimated at 0.4 per 100000 [2]. Mouse models exist but neither the CRMO etiology nor the pathogenesis is completely understood [5].

At present, there is no single test or examination to confirm the diagnosis [2,4] which is established by exclusion of infectious osteomyelitis and other diseases in combination with clinical, radiological and/or histological criteria [6]. Currently, neither invasive biopsy with histological workup nor MRI is considered to be mandatory. Radiography has been the only imaging modality that contributes a major diagnostic criterion by discovering osteolysis or osteosclerosis [6]. However, inflammatory bone lesions may be missed by radiography and scintigraphy. In the absence of better markers, chronicity of at least 6 months is being used as a diagnostic criterion. A long period of uncertainty and delay of appropriate treatment may therefore precede the definite diagnosis of CRMO.

Targeted MRI [6, 7] and whole-body MRI (WB-MRI) [8-12] have been found to be of superior sensitivity, detecting more lesions than clinical examination, radiography or scintigraphy without radiation exposure. Consequently, MRI is considered highly useful for the diagnosis and follow-up of CRMO [9-13] and is therefore frequently performed in these patients in clinical practice [2]. In the literature the available experience with WB-MRI in patients with CRMO is still limited to cohorts between 9 and 21 patients $[8-10,12]$.

In the present study, we sought to evaluate typical patterns of bone involvement in WB- MRI in a first coherent larger series of patients with confirmed CRMO and to assess its potential contribution to an earlier diagnosis

\section{Subjects and methods}

$\nabla$

53 consecutive patients who had their first WB-MRI between November 2004 and April 2010 before they were diagnosed and treated for CRMO were included in our retrospective study at a tertiary children's hospital.

Prior to MRI scanning, all patients underwent thorough clinical examination by an experienced board-certified pediatric rheumatologist (T.H.) and/or orthopedic surgeon (M.L.). Written consent was obtained from each patient or patient's legal representative before MR examination. The study was conducted in accordance with the regulations of the local review board.

Prior to the first MRI scan, no patient had received treatment other than non-steroidal anti-inflammatory drugs (NSAID), especially no second line therapy with steroids, bisphosphonates, methotrexate or biologicals.

\section{MR imaging and evaluation}

All WB-MRI scans were performed with a 1.5 Tesla scanner (Magnetom Avanto, Siemens, Erlangen, Germany), a multichannel surface coil system (Total Imaging Matrix), and parallel imaging technology (iPAT). Thoracic and abdominal imaging was navigator-triggered while patients breathed spontaneously. $2 \mathrm{D}$ coronal short Tau inversion recovery (STIR) images (TI $130 \mathrm{~ms}$, TE $83 \mathrm{~ms}$, TR $4073 \mathrm{~ms}$ (abdomen, lung, spine) or TR $8500 \mathrm{~ms}$ (head, neck, thorax, pelvis, legs), FoV max. $50 \mathrm{~cm}$, matrix $384 \times 269$, slice thickness $4 \mathrm{~mm}$, maximum voxel size $1.3 \times 1.8 \times 4 \mathrm{~mm}$ ) were acquired in each patient in four or five subsequent table positions in order to cover all body parts. In case of suspected lesions in the shoulder girdle, the spine or the pelvis these were documented by additional $4 \mathrm{~mm}$ axial or $3 \mathrm{~mm}$ sagittal STIR images. The total acquisition time was approximately 30 minutes.

MR images were retrospectively evaluated on a dedicated PACS workstation (Impax, AGFA Healthcare, Cologne, Germany) by two experienced pediatric radiologists (T.S. and T.K.). Disagreements were resolved in a consensus conference.

Lesions were scored with respect to location, number, size, signal intensity and contour (well or ill-defined). Lesions in tubular bones were classified into epiphyseal, metaphyseal and diaphyseal as well as proximal, middle or distal location. Signal intensities of representative lesions, of adjacent normal bone marrow, and of fluid in the bladder, joint or spinal canal were measured in each patient. Signal intensity ratios (SI) were calculated as SI lesion/SI normal marrow and SI lesion/SI fluid. All other lesions were visually compared to signal intensities of adjacent bone marrow and fluid. Small punctiform areas of high signal intensities are common in the bone marrow of children, especially in the feet, and are considered as remnants of red bone marrow [14]. We therefore set the minimum diameter of reported lesions to $5 \mathrm{~mm}$. To account for age dependency of bone size, osseous lesions were also categorized into smaller or larger than $50 \%$ of the transverse diameter of the bone. The border to the surrounding normal bone marrow was categorized as predominantly well-defined, ill-defined or not assessable. Diffusely elevated signal intensities in a diaphysis or in a dorsal part of a metaphysis of a long tubular bone were regarded as normal in children under the age of 15 [15]. Periosteal and soft tissue surroundings of the osseous lesions were evaluated for abnormalities.

\section{Results}

Our cohort comprised 34 female and 19 male patients, with a mean age of $11(4.8-15.1)$ years. Patients had presented with pain in their lower extremities (27 patients), their upper extremities and shoulder girdle (12), their lower back and hips (11), and/or in their back (17) including limited mobility or swelling of painful joints. 26 patients had a history of multifocal or changing complaints, 27 had unifocal symptoms. The time interval between the first, sometimes insidious, onset of clinical signs and the diagnosis of CRMO ranged from 2 days to 7 years.

CRMO was supported by histology in 37 of 53 patients. 4 additional patients had normal biopsy results without signs of osteomyelitis. The remaining 12 patients did not undergo a biopsy. In these 16 patients without histologically proven osteomyelitis, the diagnosis was established according to the criteria proposed by Jansson et al. [6] ( $\bullet$ Table 1).

\section{Locations and numbers of lesions:}

There was a corresponding MR finding to all clinically symptomatic sites. WB-MRI revealed additional pathological bone marrow lesions in most of the patients, including an asymptomatic vertebra plana in 2 children. Only 1 patient had a single lesion which 
Table 1 Diagnostic criteria of 16 patients without histological proof of CRMO. The column headings correspond to the diagnostic criteria proposed bei Jansson et al. [6]. The major criteria are listed in columns 2 to 5 , and the minor criteria in columns 6 to 11 . SAPHO syndrome: synovitis, acne, pustulosis, hyperostosis, osteitis.

Tab. 1 Diagnostische Kriterien der 16 Patienten ohne histologische Sicherung der CRMO. Spaltenüberschriften entsprechen den von Jansson et al. [6] vorgeschlagenen diagnostischen Kriterien. Hauptkriterien Spalten 2 bis 5, Nebenkriterien Spalten 6 bis 11. SAPHO Syndrom: Synovitis, Akne, Pustulose, Hyperostose, Osteitis.

\begin{tabular}{|c|c|c|c|c|c|c|c|c|c|c|}
\hline $\begin{array}{l}\text { patient } \\
\text { number }\end{array}$ & biopsy & $\begin{array}{l}\text { multifocal } \\
\text { lesions }\end{array}$ & $\begin{array}{l}\text { palmo- } \\
\text { plantar- } \\
\text { pustulosis }\end{array}$ & $\begin{array}{l}\text { radiologically } \\
\text { proven osteo- } \\
\text { lytic/sclerotic } \\
\text { bone lesion }\end{array}$ & $\begin{array}{l}\text { normal } \\
\text { blood } \\
\text { count }\end{array}$ & $\begin{array}{l}\text { good } \\
\text { general } \\
\text { state of } \\
\text { health }\end{array}$ & $\begin{array}{l}\text { mild to } \\
\text { moderately } \\
\text { elevated } \\
\text { CRP and ESR }\end{array}$ & $\begin{array}{l}\text { observation inter- } \\
\text { val longer than } \\
6 \text { months } \\
\text { (length of interval } \\
\text { in months) }\end{array}$ & $\begin{array}{l}\text { association } \\
\text { with other } \\
\text { autoimmune } \\
\text { disease }\end{array}$ & $\begin{array}{l}\text { first or second } \\
\text { degree relative } \\
\text { with autoim- } \\
\text { mune disease } \\
\text { or syndrome }\end{array}$ \\
\hline 1 & + & + & & & + & + & & $+(50)$ & & \\
\hline 2 & + & + & & & + & + & + & $+(19)$ & & \\
\hline 3 & + & + & & & + & & + & $+(46)$ & & \\
\hline 4 & + & + & & & + & + & & $+(59)$ & & \\
\hline 5 & - & + & & & + & & + & $+(29)$ & & \\
\hline 6 & - & + & & & & + & + & $+(26)$ & $\begin{array}{l}\text { +(Crohn's } \\
\text { disease) }\end{array}$ & \\
\hline 7 & - & + & & & + & + & & $+(40)$ & & \\
\hline 8 & - & + & & & + & + & & $+(11)$ & & $\begin{array}{l}\text { + (aunt with } \\
\text { enteropathy) }\end{array}$ \\
\hline 9 & - & + & & & & + & + & $+(43)$ & & \\
\hline 10 & - & + & + & & & & & & & \\
\hline 11 & - & + & & & + & + & & $+(24)$ & & \\
\hline 12 & - & + & & & + & + & & $+(50)$ & & \\
\hline 13 & - & + & & + & & & & & & \\
\hline 14 & - & + & & & + & + & + & $+(9)$ & & $\begin{array}{l}+ \text { (sister with } \\
\text { CRMO) }\end{array}$ \\
\hline 15 & - & + & & & + & + & & $+(32)$ & & \\
\hline 16 & - & + & $+(\mathrm{SAPHO})$ & & & & & & & \\
\hline
\end{tabular}

was located in the right clavicle. There were two patients with two lesions which were in the sacrum and tibia and the sacrum and lumbar spine.

The predominantly affected anatomic regions were the pelvis and hips (including the proximal femur), knees, ankles, feet, spine, and shoulder girdle (including clavicula, scapula, proximal humerus) as shown in $\bullet$ Fig. 1. We found bilateral symmetrical lesions in 40 of $53(75 \%)$ patients ( $24.5 \%$ of all affected bones) ( Fig. $2-4$ ).

In total, there were 513 lesions in 456 bones of 53 patients resulting in 1 to 27 (median 8, mean 9.7) osseous lesions per patient. 26 different types of bones were involved. Only the skull was spared. The scapula ( 3 lesions in a coracoid), mandible ( 2 patients) and hands ( 1 patient) were rarely involved. By far the most lesions were detected in the tibia (93 lesions in 65 bones), femur (75 in 51 bones), and sacrum (38 in 27 bones) ( Fig. 2). $50 \%$ of sacral lesions were adjacent to a sacroiliac joint ( Fig. 3). $54 \%$ of 64 lesions in the ilium, ischium and pubic bone were predominantly in the acetabulum adjacent to the triradiate cartilage (31 hips, 0 Fig. 3). There were 43 spinal lesions in 19 patients and 10 patellar lesions in 7 patients. 93 of 513 lesions (18.1\%) in 23 patients (43.3\%) were located in the feet with the largest number of pathological signal intensities in metatarsal $(n=27)$, cuneiform $(\mathrm{n}=25)$ and navicular $(\mathrm{n}=21)$ bones.

222 lesions were detected in 123 tubular bones. $51 \%$ included the epiphysis and $86.5 \%$ were adjacent to one or both sides of an epiphyseal or apophyseal growth plate ( $\bullet$ Fig. 3,4 ). The diaphyses were rarely involved. The locations were epiphyseal $(n=42$; $18.9 \%$, metaphyseal $(n=67 ; 30.2 \%)$, epi/metaphyseal $(n=69$;
$31.1 \%)$, diaphyseal $(n=4 ; 1.8 \%)$, apophyseal $(n=4 ; 1.8 \%)$, apometaphyseal ( $n=10 ; 4.5 \%)$, meta/diaphyseal $(n=23 ; 10.4 \%)$, epi/ meta/diaphyseal $(n=3 ; 1.4 \%)$.

\section{Morphological characteristics of lesions:}

Almost all (510 of 513) lesions were of high signal intensity. According to visual assessment, the signal intensities of 250 lesions ( $49 \%$ ) were higher than that of normal bone marrow but lower than that of fluid. This impression was confirmed by SI ratios of 1.3 to 3.5 compared to bone marrow, and $0.3-0.7$ to fluid. 263 lesions ( $51.3 \%$ ) had inhomogeneous parts with signal intensities as high as that of fluid (SI ratio to normal marrow 1.7-5.2 and to fluid $0.8-1.3$ ). As far as assessment was possible with a relatively low spatial resolution of WB- MRI sequences, no cortical destruction was detected except for collapsed vertebra.

386 of 513 lesions (75.2\%) took up more than half of the axial bone diameter. In each single slice the borders between lesions and normal bone marrow had a geographic configuration. They were mainly well-defined in 292 cases (56.9\%) and ill-defined in 110 cases $(21.4 \%)$. In the remaining cases the affected bone was completely involved.

A total of 33 bone deformations (7\% of bones) were detected in 22 patients. 15 bones such as clavicula, mandibula, pelvic bones, ribs and tubular bones were enlarged. However, an abnormal form in the spine (18 vertebrae) always meant a loss of volume including 6 vertebrae with a considerable loss of height ( $\bullet$ Fig.5). 2 patients with a vertebra plana had decreased mobility of their spine but had not presented because of back pain. 


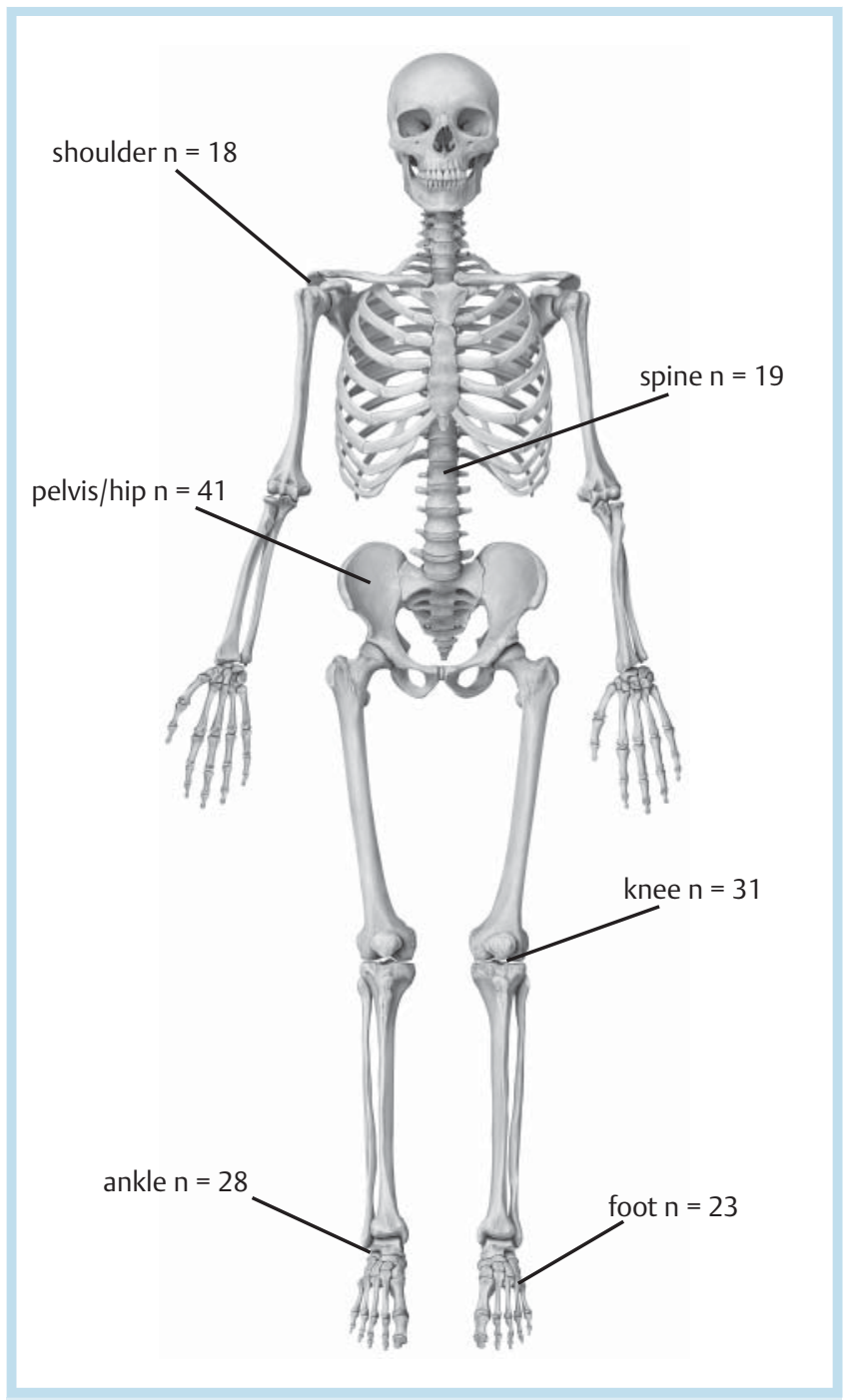

Fig. 1 Anatomic regions predominantly involved in 53 patients with confirmed CRMO. Given as number of patients with pathological osseous lesions in the annotated region.

Abb. 1 Die am häufigsten beteiligten anatomischen Regionen bei $53 \mathrm{~Pa}-$ tienten mit gesicherter CRMO. Angegeben als Anzahl der Patienten mit pathologischen Knochenläsionen in der beschrifteten Region.

\section{Surrounding tissue}

In 162 osseous lesions (31.6\%) the surrounding, slightly thickened periost, joint and/or soft tissue showed increased signal intensity in STIR images including sacral and spinal sites. No soft tissue mass was observed (0 Fig. 2-4).

\section{Other findings}

In 39 patients radiographs of the symptomatic sites were available. They showed abnormalities such as sclerosis and/or osteolysis in 20 patients and were normal in 19.

In addition to their osseous lesions, 3 children had palmoplantar pustulosis, 1 child suffered from neurodermatitis, 1 child had celiac disease and a petechial rash, 1 child had Crohn's disease, and round lung lesions were found in 2 children.

\section{Characteristic patterns:}

Scrutinizing WB-MR images for multifocal lesions that are located metaphyseal or epi/metaphyseal adjacent to a growth plate

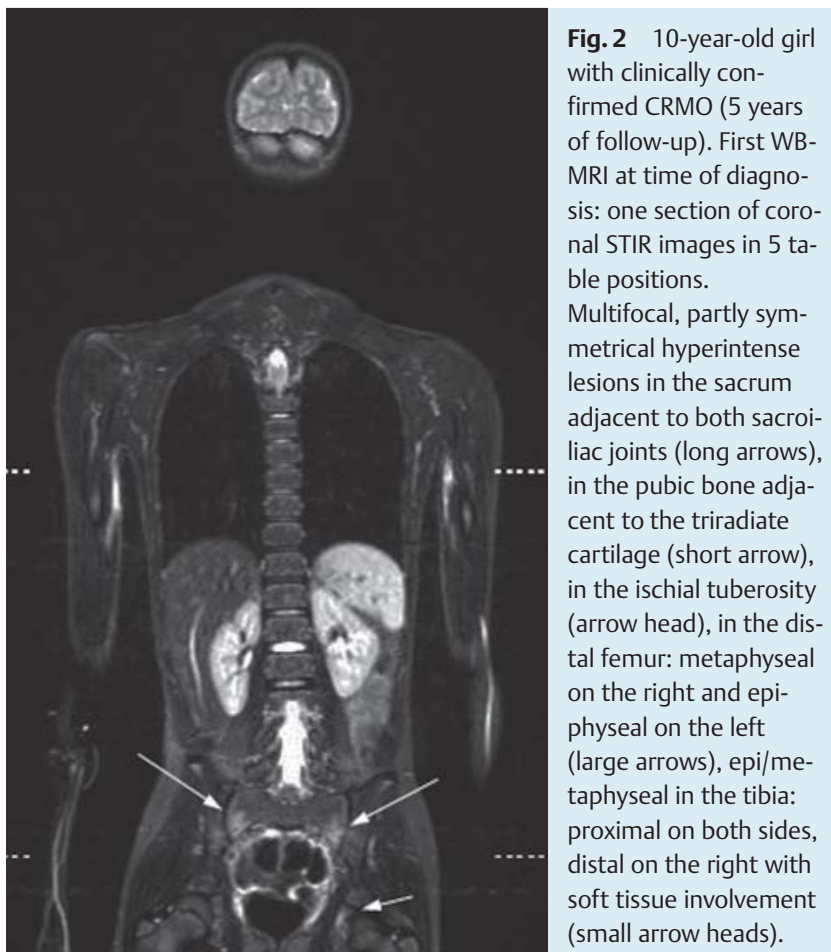

Abb. 210 Jahre altes Mädchen mit klinisch gesicherter CRMO $(5$ Jahre Beobachtungszeitraum). Erste Ganzkörper-MRT zum Zeitpunkt der Diagnosestellung: Schnitt einer coronaren STIR-Sequenz in 5 Tischpositionen. Multifokale, teilweise symmetrische hyperintense Läsionen im Sakrum angrenzend an beide lliosakralfugen (lange Pfeile), im Os pubis angrenzend an die Y-Fuge (kurzer Pfeil), im Tuber ischiadicum (Pfeilspitze), im distalen Femur: metaphysär rechts und epiphysär links (große Pfeile), epi/ metaphysär in der Tibia: proximal beidseits, distal rechts mit Weichteilbeteiligung (kleine Pfeilspitzen). 


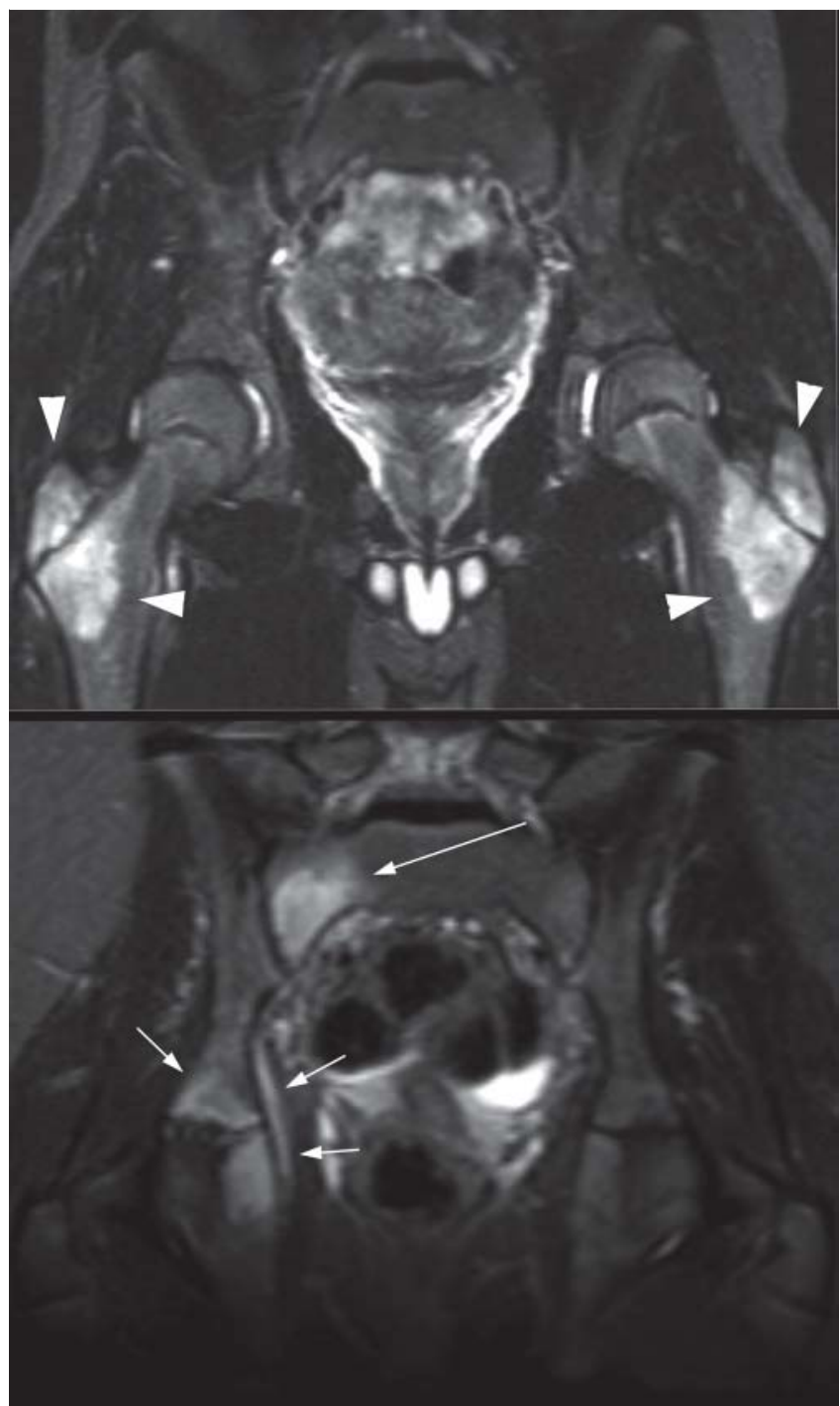

Fig. 3 Typical involvement of the pelvis and hip region in two adolescents with histologically confirmed CRMO. 15-year-old boy (above) with symmetrical lesions adjacent to the apophyseal growth plate of the greater trochanter (arrow heads). 13-year-old girl (below): unilateral lesions in the sacrum involving the whole width of the right ala (long arrow) and in the acetabulum adjacent to the triradiate cartilage with soft tissue involvement (short arrows). STIR coronal.

Abb. 3 Typische Beteiligungen von Becken und Hüftregion bei 2 Adoleszenten mit histologisch gesicherter CRMO. 15 Jahre alter Junge (oben) mit symmetrischen Läsionen angrenzend an die apophysäre Wachstumsfuge des Trochanter major (Pfeilspitzen). 13 Jahre altes Mädchen (unten) einseitige Läsionen im Sakrum die gesamte Breite der rechten Ala betreffend (langer Pfeil) und im Acetabulum angrenzend an die Y-Fuge mit Beteiligung der Weichteile (kurze Pfeile). STIR coronar.

The remaining 12 patients had no metaphyseal involvement of their lower extremities (only epiphyseal or no lesions). 7 of them could be identified by typical lesions in their pelvis adjacent to the sacroiliac joint or the triradiate cartilage. 4 had lesions in the spine and/or clavicle, and one patient had only one clavicular lesion.

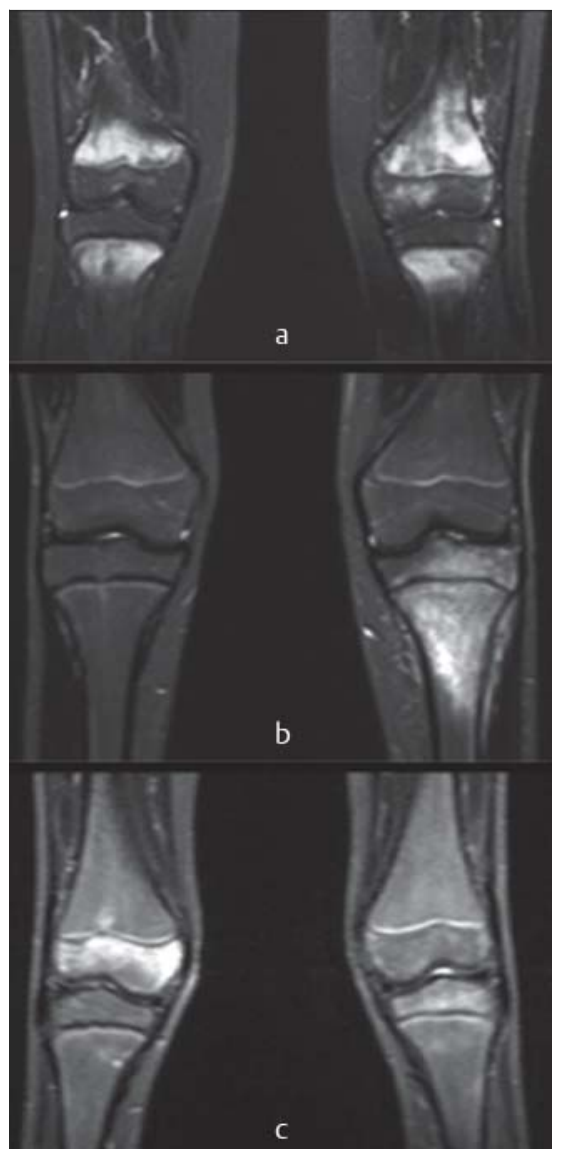

Fig. 4 Spectrum of epi/metaphyseal involvement in the knee regions of three girls with histologically confirmed CRMO. 7-year-old a with symmetrical metaphyseal lesions adjacent to the growth plates. 12-year-old $\mathbf{b}$, epiphyseal and metaphyseal lesion with soft tissue involvement. 7-year-old c with epiphyseal involvement of the distal right femur and the proximal left tibia. STIR coronal.

Abb.4 Spektrum der epi/metaphysären Beteiligung der Knieregionen dreier Mädchen mit histologisch gesicherter CRMO. 7 Jahre alt a mit symmetrischen metaphysären Läsionen angrenzend an die Epiphysenfuge. 12 Jahre alt b, epi- und metaphysäre Läsion mit Weichteilbeteiligung. 7 Jahre alt $\mathbf{c}$ mit epiphysärer Beteiligung des distalen rechten Femur und der proximalen linken Tibia. STIR coronar.

\section{Discussion}

\section{$\nabla$}

Nearly one-fifth of preteens and young adolescents are reported to experience new-onset musculoskeletal pain over a one-year period [16]. Among these frequent complaints, it can be quite challenging for a clinician to properly distinguish more significant symptoms, which probably contributes to the frequent delay of diagnosis in the case of CRMO. If children with persistent nonspecific musculoskeletal pain are referred for diagnostic imaging, clear and specific criteria may allow a radiologist to suggest the correct diagnosis early, and thus help to prevent complications of CRMO in a significant percentage of cases.

Our coherent WB-MRI series of 53 consecutive patients indicates that in most of the cases CRMO indeed shows a recognizable pattern of bone involvement which may lead to the correct diagnosis. $75 \%$ of our patients could have been identified by multifocal, hyperintense geographic metaphyseal lesions adjacent to growth plates of the long bones of the lower extremities combined with either bilateral symmetrical involvement ( $\bullet$ Fig. 2 ), or additional 


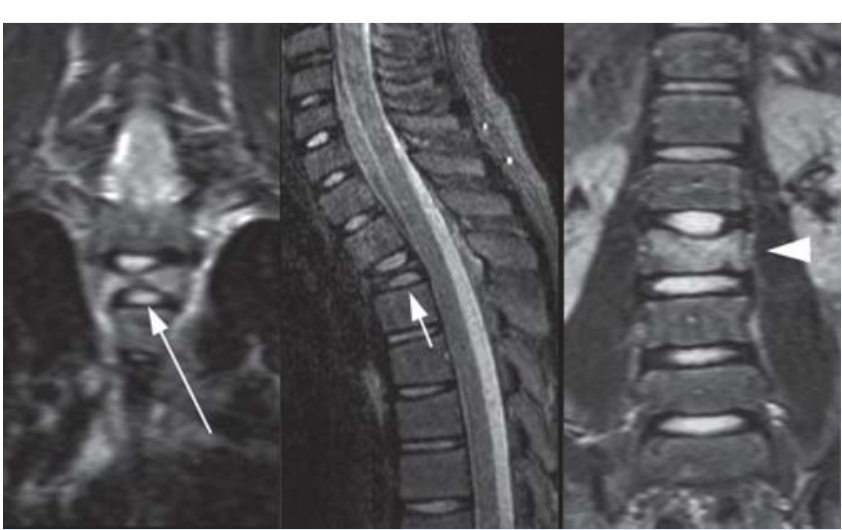

Fig. 5 13-year-old boy with histologically confirmed CRMO. Thoracic vertebra plana (T3): Detection in the coronal STIR sequence (long arrow) more difficult than in the sagittal plane (short arrow). Lesion in the lumbar vertebra (L3) obvious in the coronal plane (arrow head).

Abb. 513 Jahre alter Junge mit histologisch gesicherter CRMO. Thorakale vertebra plana, (Th3): Nachweis in der coronaren STIR Sequenz (langer Pfeil) schwieriger als in der sagittalen Ebene (kurzer Pfeil). Läsion in lumbalem Wirbelkörper (L3) gut sichtbar in der coronaren Ebene (Pfeilspitze).

lesions in the spine, pelvis, clavicle and/or sternum ( $\bullet$ Fig. 3,5 ). We believe that these combinations of at least two typical MRI findings render a patient highly suspicious of CRMO.

The remaining $25 \%$ of our patients had lesions in locations such as the spine, pelvis, clavicle and/or sternum which have been considered as typical $[4,7,9,17]$ but were lacking the characteristic lesions in the metaphyses of their lower extremities. Regarding the differential diagnoses, we would therefore consider the WB-MRI of these patients as suspicious but less specific for CRMO.

Although each single MR finding is not entirely specific to CRMO, our study indicates that combinations and typical patterns of lesions are important diagnostic clues towards the right clinical diagnosis $[17,18]$. Together with its superior sensitivity for the total number, the location and the possible symmetry of lesions, WB-MRI appears to be more suitable as a major radiological criterion for the diagnosis of CRMO than radiographs which were negative in $50 \%$ of cases. We would therefore recommend radiographs to document bone deformities and malalignment, or to rule out a fracture but not to establish the diagnosis.

To rule out differential diagnoses, the synopsis of MRI and clinical findings remains crucial. In cases in which the clinical course and radiological findings are not typical and histological confirmation is still necessary, WB-MRI may help to indicate the optimum site for a biopsy. The lack of radiation exposure is an important advantage for therapy monitoring by WB-MRI.

In addition to earlier observations in WB-MRI of smaller groups of patients $[9,12]$, our data indicate that all skeletal regions except for the skull can be involved. We especially found higher rates of spinal abnormalities (36\% of our patients) and bone deformations ( $42 \%$ of our patients). We found lesions in the patella and the metatarsals, which have rarely been described $[6,19]$. Our data confirm that epiphyseal involvement and periosteal reaction without mass effect are part of the spectrum of CRMO $[7,9,10]$, including the periost of the spine and sacrum, and are not as rare as previously reported $[20,21]$.

The large variety of locations highlights the necessity to completely include the whole skeleton in the WB-MRI. According to our experience, rib lesions may escape detection when respiratory triggering is not used. Spinal, sacral, scapular, sternal or patellar lesions may be difficult to assess in coronal images ( $\boldsymbol{0}$ Fig.5). Especially in the cervical and thoracic spine we find it helpful to load the $4 \mathrm{~mm}$ coronal sections into a $3 \mathrm{D}$ tool of our workstation and to adjust the coronal plane so that a more continuous spinal section is visible. In case of known or suspected vertebral or sacral lesions, we recommend sequences in sagittal orientation to improve their delineation.

Previous studies with targeted imaging have routinely underestimated the characteristic bilateral distribution and the number of lesions per patient. Bilateral lesion ( $75 \%$ of our patients) are more frequently reported in whole-body imaging $[9,22]$ than in targeted examinations (22\%) [6]. The median of 8 lesions per patient (mean 9.7) in our study was higher than the $3-5$ lesions per patient in studies with mostly targeted radiological examinations $[6,10]$. Although $50 \%$ of our patients reported only unifocal pain, WB-MRI revealed multifocal lesions in all but one of them. Correspondingly, the frequency of unifocal lesions (2\%) was much lower than those published for targeted imaging (34\% [2] and $30 \%$ [4]). We detected lower rates of clavicular (4\%) and calcaneal (1\%) lesions compared to $24 \%$ and $19 \%$ [4] but a higher rate of sacral lesions ( $7 \%$ of lesions in $51 \%$ of patients) compared to rare involvement $[19,20]$. The frequency of spinal lesions $(36 \%$ of our patients) was in the upper range of the largely varying published data $[4,16,23]$. A possible explanation is that lesions at some sites may have a higher tendency to become clinically evident than others and may therefore be more likely to be detected by targeted imaging. It is important that even a considerable loss of vertebral height could be subjectively asymptomatic not only in our cohort [2,3]. Without WB-MRI these lesions may remain undetected and cannot be reliably classified as new or progressive later in the course of the disease. An information that may affect important therapeutic considerations such as the introduction of the second-line agents steroids, methotrexate, biphosphonates or tumor necrosis factor $\alpha$-blockers $[3,10$, 24].

The main differential diagnoses of CRMO include infectious as well as malignant diseases [17]. Langerhans cell histiocytosis ( $\mathrm{LCH}$ ) has to be considered especially in the case of a vertebra plana $[13,25]$. However, asymmetrical diaphyseal bone lesions, skull lesions and hypophyseal involvement are much more typical of LCH and may therefore help to differentiate the two entities [26]. Non-Hodgkin lymphoma may present as primary multifocal osseous disease but cortical destruction [27] and additional sites of involvement such as lymph nodes or parenchymal organs are common [28] and can help to differentiate both entities. Together with clinical findings, symmetry and multifocal involvement adjacent to growth plates without cortical erosions may help to distinguish CRMO from malignant diagnoses such as leukemia, metastases or an early stage of Ewing's sarcoma without soft tissue tumor. However, in uncertain cases especially with unifocal lesions, biopsy remains mandatory.

Differentiating CRMO from bacterial osteomyelitis or spinal lesions from bacterial spondylitis and spondylodiscitis may be difficult [20]. We found bone deformation and edema of the adjacent soft tissue but we observed neither formations suspicious for an abscess nor involvement of vertebral discs. Sacroiliitis may affect the cortex and marrow adjacent to the joint but rarely extends deep into inner parts of the sacrum as in 32 of 38 sacral lesions of our patients ( $\bullet$ Fig. 3 ). 


\section{Limitations}

NSAID pretreatment, arbitrary cutoff at a size of $5 \mathrm{~mm}$ and STIR imaging may have induced an underreporting of lesions in this retrospective study. NSAIDs may have influenced the number and aspect of the lesions in MR images but are unlikely to influence their distribution and location. To keep the duration of the MR examination within acceptable limits for children, our routine protocol only consisted of STIR images. Hypointense lesions may therefore be more easily overlooked than hyperintense ones. The lack of data on interobserver agreement may be considered as a weakness of our study. Disagreement occurred when one observer had overlooked a lesion. There was very high interobserver agreement on the size of a hyperintense focus and its classification as pathological or normal. Therefore, we decided to merge both records after the consensus meeting.

\section{Conclusion}

\section{$\nabla$}

In the absence of more specific diagnostic tests and criteria, whole-body MRI with STIR sequences can, in synopsis with clinical findings, substantially contribute to an early identification of patients with CRMO and thus help to reduce the time between onset and diagnosis. It discovers the typical pattern of multifocal and bilateral bone involvement in CRMO more often than has been reported for targeted MRI and consequently more often than clinical examination, radiography or scintigraphy. It readily reveals the coexistence of geographic hyperintense lesions in typical locations such as lower extremities, pelvis, shoulder girdle and spine, and shows their characteristic proximity to growth plates, sacroiliac joints and triradiate cartilage. We reasoned that combinations of these findings render a patient highly suspicious for CRMO and might therefore serve as a major diagnostic criterion. Additionally, WB-MRI may help to uncover asymptomatic vertebral compressions, to indicate the best site for a biopsy, or to avoid an invasive procedure altogether.

\section{References}

1 Giedion A, Holthusen W, Masel LF et al. Subacute and chronic "symmetrical" osteomyelitis. Ann Radiol 1972; 15 (3): 329-342

2 Jansson AF, Grote V. ESPD Study group. Nonbacterial osteitis in children: data of a German incidence surveillance study. Acta Paediatrica 2011; 100: 1150 - 1157

3 Hospach T, Langendoerfer $M$, von Kalle $T$ et al. Spinal involvement in chronic recurrent multifocal osteomyelitis (CRMO) in childhood and effect of pamidronate. Eur J Pediatr 2010; 169: 1105-1111

4 Girschick HJ, Raab P, Surbaum S et al. Chronic non-bacterial osteomyelitis in children. Ann Rheum Dis 2005; 64: 279-285

5 Hofmann SR, Roesen-Wolff A, Hahn G et al. Update: Cytokine dysregulation in chronic nonbacterial osteomyelitis (CNO). Int J Rheumatol 2012; 2012: 310206 Epub 2012 May 21

6 Jansson A, Renner ED, Ramser J et al. Classification of non-bacterial osteitis: retrospective study of clinical, immunological and genetic aspects in 89 patients. Rheumatology (Oxford) 2001; 46: 154-160

7 Falip C,Job-Deslandre C, Boutry N et al. Chronic recurrent multifocal osteomyelitis (CRMO): A review of imaging findings in 21 patients. Pediatr Radiol 2009; 39: S573
8 Atkin K, Jelbert A, Johnson K. Chronic recurrent multifocal osteomyelitis (CRMO): a 14-case series review of imaging features, an evaluation of our experience of whole-body STIR-MRI in initial investigation and follow-up. Pediatr Radiol 2008; 38: S537

9 Fritz J, Tzaribatchev N, Claussen C et al. Chronic recurrent multifocal osteomyelitis: comparison of whole-Body MR imaging with radiography and correlation with clinical and laboratory data. Radiology 2009; 252: $842-851$

10 Beck C, Morbach H, Beer M et al. Chronic nonbacterial osteomyelitis in childhood: prospective follow-up during the first year of anti-inflammatory treatment. . Arthritis, Research \& Therapy 2010; 12 (2): R74

11 Kennedy MT, Murphy T, Murphy M et al. Whole body MRI in the diagnosis of chronic recurrent multifocal osteomyelitis. Orthop Traumatol Surg Res 2012; 98(4: 461 - 464 Epub 2012 May 11

12 Guérin-Pfyffer S, Guillaume-Czitrom S, Tammam $S$ et al. Evaluation of chronic recurrent multifocal osteitis in children by whole-body magnetic resonance imaging. Joint Bone Spine 2012; DOI: 10.1016/ j.jbspin.2011.12.001

13 Schäfer JF, Kramer U. Ganzkörper-MRT bei Kindern und Jugendlichen. Fortschr Röntgenstr 2011; 183: 24-36

14 Shabshin N, Schweitzer M, Morrison W et al. High-signal T2 changes of the bone marrow of the foot and ankle in children: red marrow or traumatic changes? Pediatr Radiol 2006; 36: 670-676

15 Laor T, Jaramillo D. MR Imaging insights into skeletal maturation: what is normal? Radiology 2009; 250: $28-38$

16 El-Metwally A, Salminen JJ, Auvinen A et al. Risk factors for development of non-specific musculoskeletal pain in preteens and early adolescents: a prospective 1-year follow-up study. BMC Musculoskeletal Disorders 2007; 8: 46. DOI: 10.1186/1471-2474-8-46

17 Jansson A, Müller TH, Gliera L et al. Clinical score for nonbacterial Osteitis in children and adults. Arthritis \& Rheumatism 2009; 60: 1152 - 1159

18 Morbach H, Schneider P, Schwarz T et al. Comparison of magnetic resonance imaging and 99mTechnetium-labelled methylene diphosphonate bone scintigraphy in the initial assessment of chronic non-bacterial osteomyelitis of childhood and adolescents. Clin Exp Rheumatol 2012; 30: 578 - 582 Epub 2012 Aug 29

19 Khanna G, Sato TSP, Ferguson P. Imaging of chronic recurrent multifocal osteomyelitis. RadioGraphics 2009; 9: 1159-1177

20 Jurik AG, Egund N. MRI in chronic recurrent multifocal osteomyelitis. Skeletal Radiol 1997; 26: 230-238

21 Iyer RS, Thapa MM, Chew FS. Chronic recurrent multifocal osteomyelitis: Review. Am J Roentgenol 2011; 196 (6): S87 -S91

22 Mandell GA, Contreras SJ, Conard $K$ et al. Bone scintigraphy in the detection of chronic recurrent multifocal osteomyelitis. J Nucl Med 1998; 39: $1778-1783$

23 Schilling $F$, Fedlmeier $M$, Eckardt A et al. Wirbelsäulenmanifestationen der chronischen rekurrierenden multifokalen Olsteomyelitis (CRMO). Fortschr Röntgenstr 2002; 174: 1236-1242

24 Miettunen PMH, Wei X, Kaura D et al. Dramatic pain relief and resolution of bone inflammation following pamidronate in 9 pediatric patients with persistent chronic recurrent multifocal osteomyelitis (CRMO). Pediatric Rheumatology 2009; DOI: 10.1186/1546-0096-7-2

25 Steinborn M, Wörtler K, Nathrath $M$ et al. Ganzkörper-MRT bei Langerhans-Zell-Histiozytose im Kinder- und Jugendalter zur Beurteilung des Skelettsystems. Fortschr Röntgenstr 2008; 180: 646-653

26 Vollmann R, Lutfi A, Simbrunner J. Die Langerhans-Zell-Histiozytose als Ursache für einen zentralen Diabetes insipidus: typischer zerebraler MRT Befund. Fortschr Röntgenstr 2012; 183: 258-259

27 Sato T, Ferguson PJ, Khanna G. Primary multifocal osseous lymphoma in a child. Pediatr Radiol 2008; 38: $1338-1341$

28 Kellenberger CJ, Miller SF, Khan $M$ et al. Initial experience with FSE STIR whole-body MR imaging for staging of lymphoma in children. Eur Radiol 2004; 14: 1829-1841 